Олег Михайлович Воробйов (доктор техн наук, професор) ${ }^{1}$

Олександр Михайлович Сотніков (доктор техн наук, професор) $)^{2}$

Олександр Борисович Танцюра ${ }^{2}$

${ }^{1}$ Національний університет оборони Украӥни імені Івана Черняховського, Київ, Украӥна

${ }^{2}$ Харківський національний університет Повітряних Сил імені Івана Кожседуба, Харків, Украӥна

\title{
МОДЕЛІ ПОТОЧНИХ ЗОБРАЖЕНЬ, ЩО ФОРМУЮТЬСЯ КАНАЛАМИ КОМБІНОВАНОЇ КОРЕЛЯЦІЙНО-ЕКСТРЕМАЛЬНОЇ СИСТЕМИ НАВІГАЦІЇ БЕЗПІЛОТНОГО ЛІТАЛЬНОГО АПАРАТУ
}

Здійснено уточнення моделей поточних зображень, щу формуються окремими каналами комбінованої корелячійно-екстремальної системи навігації в залежності від просторового положення безпілотного літального апарату та його зміни. В моделях враховано вплив тримірної форми складних об'єктів поверхні візування на ефективну антенну температуру радіометричного каналу та на яскравість телевізійного каналу. Це дозволило здійснити уточнення моделей опису радіометричного та телевізійного поточного зображення поверхні візування в залежності від інформативних ознак. Визначено, щуо при малих висотах візування зміна просторового положення безпілотного літального апарату призводить до суттєвих перепадів радіояскравісної температури в межах одного об'єкту візування, щь обумовлює розмиття та появу нових границь розділу на поточному зображенні поверхні візування. Невідповідність поточного зображення еталонному, яка виникає внаслідок появи нових границь розділу при візуванні складних тримірних об'єктів з малих висот та при зміні просторового положення $i$ орієнтації безпілотного літального апарата призводить до формування багатоекстремальної вирімальної функції та зменшенню точності місчевизначення кореляційноекстремальної системи навігації.

Ключові слова: радіояскравісна температура; тримірний об'єкт візування; поточне зображення; просторове положення; комбінована кореляційно-екстремальна система навігації; безпілотний літальний апарат.

\section{Вступ}

Сучасний стан розвитку безпілотних літальних апаратів (БпЛА) дозволяє вирішувати широкий спектр важливих задач, від ретрансляції потоків даних, до розвідки та нанесення високоточних ударів в будь яких умовах оперативно-тактичної обстановки (ОТО). Зважаючи на це, до систем навігації БпЛА висувається ряд вимог, виконання яких необхідне для успішного виконання покладених на них завдань. Основними 3 таких вимог є:

- висока точність навігації БпЛА в умовах складної OTO;

- максимально можлива перешкодозахищеність;

- максимально можлива метеонезалежність;

- працездатність в різний час доби та року;

- можливість оперативної зміни траєкторії польоту в реальному вимірі часу;

- мінімальні масо-габаритні характеристики.

Для забезпечення цих вимог інерційні навігаційні системи БпЛА корегуються за допомогою супутникових навігаційних систем (СНC) або кореляційно-екстремальних систем навігації (КЕСН). Використання СНC не забезпечує виконання умов перешкодозахищеності системи, до того ж країни, що не мають власної СНС можуть бути обмежені у застосуванні БпЛА 3 такою системою в окремих районах [1]. Тому для корекції траєкторії польоту БпЛА все частіше застосовуються комбіновані КЕСН різноспектральними каналами отримання інформації про поверхню візування (ПВ), що обумовлено забезпеченням вимог до систем навігації.

У повному обсязі вимогам до систем навігації відповідають комбіновані КЕСН 3 телевізійним (ТВ) та радіометричним (РМ) каналами отримання інформації.

Постановка проблеми. В КЕСН пошук об'єктів прив'язки (ОП) на поточному зображенні (ПЗ) поверхні візування (ПВ) здійснюється шляхом порівняння його фрагментів 3 еталонним зображенням (Е3). Однак отримання інформації РМ каналом про складні тримірні об'єкти при візуванні 3 малих висот, навіть при незначних змінах просторового положення БПЛА, призводить до різких перепадів радіояскравісної температури в межах одного об'єкта візування. Це обумовлює появу нових меж розділу між окремими елементами самого об'єкту, зміщення, розмиття або появу нових контурів на ПЗ ПВ. При отриманні інформації про ПВ ТВ каналом, ті ж самі фактори призводять до появи тональної перспективи. В результаті виникає невідповідність між поточним та еталонним зображеннями ПВ, що призводить до формування багатоекстремальної вирішальної функції (ВФ) i, як наслідок, до зменшення точності місцевизначення КЕСН.

Оскільки радіометр має жорстку зв'язку 3 корпусом БпЛА, на відміну від датчика ТВ каналу 
який, як правило, встановлюється на трьохосній стабілізованій платформі, то на формування ПЗ ПВ в РМ каналі суттєво впливають випадкові зміни просторового положення БпЛА, обумовлені поривами вітру та турбулентністю атмосфери. В такому випадку виникає необхідність урахування зміни просторового положення та орієнтації БпЛА і складної тримірної форми об'єктів візування при формуванні ПЗ ПВ в РМ каналі комбінованої КЕСН 3 метою усунення структурної невідповідності між поточним та еталонним зображеннями ПВ, що дозволить сформувати унімодальну ВФ.

Аналіз остатніх досліджень і публікацій. На теперішній час відомі методи та алгоритми формування унімодальної ВФ в умовах афінних та геометричних спотворень ПЗ ПВ [2 - 4] однак в цих роботах випадок морфологічного спотворення ПЗ ПВ не розглядався. Розроблені методи синтезу ЕЗ для радіометричних КЕСН, однак у відомих роботах $[5,6]$, не розкриті питання структурної невідповідності поточних зображень еталонним при випадковій зміні просторового положення та орієнтації БпЛА. Відомі моделі, що описують процес формування ПЗ ПВ при застосуванні радіометричних КЕСН на ділянках місцевості зі слабоконтрастними та малорозмірними об'єктами [7, 8]. У той же час не отримали детального дослідження питання впливу тримірності об'єктів на ПВ, що призводить до виникнення нових контурів на ПЗ та розмитості контурів між об'єктами. Особливо - це стосується випадку коли на ПВ є несиметричні різновисокі об'єкти, тіні від яких будуть суттєво відрізнятися в залежності від кутів орієнтації та просторового положення БПЛА. При цьому ситуація з формуванням ПЗ, близького до еталону, ще більш ускладнюється в умовах прив'язки БпЛА до слабоконтрастних об'єктів та при наявності перешкод, що призводять до зменшення відношення сигнал/шум на вході датчиків КЕСН. Таким чином для формування унімодальної ВФ в умовах випадкової зміни просторового положення та орієнтації БпЛА, а також при візуванні різновисоких тримірних об'єктів, необхідно враховувати вплив цих факторів на формування ПЗ ПВ.

Метою статті $\epsilon$ уточнення моделей поточних зображень, що формуються окремими каналами комбінованої кореляційно-екстремальної системи навігації, 3 урахуванням випадкової зміни просторового положення та орієнтації БпЛА i тримірності об'єктів візування.

\section{Виклад основного матеріалу дослідження.}

Відомо, що показник точності КЕСН БПЛА у спрощеному вигляді визначається за виразом:

$$
\sigma_{\mathrm{k}}=\sqrt{\sigma_{\text {пл }_{\mathrm{i}}}^{2}+\sigma_{\Pi_{\mathrm{k}}}^{2}+\sigma_{\mathrm{cy}}^{2}}
$$

де $\sigma_{\text {пл }}=\mathrm{f}\left(\sigma_{\mathrm{E} 3}, \sigma_{\mathrm{x}_{\mathrm{i}} \mathrm{y}_{\mathrm{i}} \mathrm{z}_{\mathrm{i}}}\right)-$ СКП локалізації i-го ОП на ПЗ при $\mathrm{k}$-му сеансі прив'язки, яка залежить від точності виготовлення E3 $\sigma_{\mathrm{E} 3}$ та похибок визначення просторового положення БпЛА

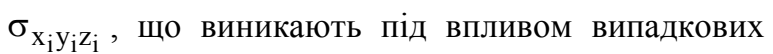
факторів;

$\sigma_{\Pi_{\mathrm{k}}}-$ СКП визначення координат після виконання корекції на k-му сеансі прив'язки $\mathrm{KECH}$;

$\sigma_{\mathrm{cy}_{\mathrm{k}}}-$ СКП відпрацювання сигналів управління після проведення корекції траєкторії польоту БПЛА.

Уточнення моделі ПЗ, що формується окремими каналами комбінованої КЕСН будемо здійснювати з урахуванням:

- СКП БІНС;

- впливу тримірної форми об'єктів ПВ на результат виміру яскравості ТВ датчиком $\mathrm{B}_{\text {я }}$, $\mathrm{a}$ також радіояскравісної температури радіометром $\Delta \mathrm{T}_{\mathrm{A}_{\mathrm{eq}}}$

- випадкової зміни просторового положення БпЛА, обумовленої поривами вітру та атмосферною турбулентністю, яку не може миттєво компенсувати БІНС.

Вплив СКП БІСН в моделі врахуємо залежністю тілесного кута діаграми спрямованості антени (ДСА) $\Omega$ А від просторового положення БпЛА та його зміни, що визначається кутами $\gamma^{\prime}, \theta^{\prime}, \psi^{\prime}$ :

$$
\Omega_{\mathrm{A}}=\Omega_{\mathrm{A}}\left(\gamma^{\prime}, \theta^{\prime}, \psi^{\prime}\right)
$$

де $\gamma^{\prime}=\gamma \pm \Delta \gamma-$ поточне значення кута крену;

$\theta^{\prime}=\theta \pm \Delta \theta-$ поточне значення кута тангажа;

$\psi^{\prime}=\psi \pm \Delta \psi-$ поточне значення кута рискання.

Вплив тримірної форми об'єктів ПВ на результат виміру яскравості ТВ датчиком $\mathrm{B}_{\text {я }}$, $\mathrm{a}$ також радіояскравісної температури $\Delta \mathrm{T}_{\mathrm{A}_{\mathrm{e \phi}}}$ радіометром обумовлює необхідність уточнення цих параметрів шляхом урахування вкладу в їх інтегральні значення окремих сторін.

Зображення ПВ отримані окремими каналами КЕСН доцільно описувати 3 використанням єдиного показника якості. Таким показником може бути інформативний параметр, що вимірюється відповідним датчиком комбінованої КЕСН. В нашому випадку інформативними параметрами для ТВ зображення є яскравість та контраст, а для PM зображень радіотеплова температура та радіотепловий контраст.

Розглянемо окремо для кожного 3 каналів КЕСН підхід щодо опису зображень ПВ, які формуються датчиками різної фізичної природи.

Зображення ПВ за допомогою ТВ датчика може бути представлене у кольоровому вигляді. Але, обробка таких зображень повинна здійснюватися за окремими кольоровими складовими $[9,10]$. Тому для забезпечення єдності 
представлення інформації про ПВ елементи ТВ зображення будемо описувати градаціями сірого через параметр яскравості.

Яскравість, що приймається ТВ датчиком КЕСН від об'єкта ПВ розміщеного в точці $(\mathrm{i}, \mathrm{j})$ у момент часу $\mathrm{t}$ відповідно до [2] представимо у наступному вигляді:

$$
\mathrm{B}_{\mathrm{r}}(\mathrm{i}, \mathrm{j}, \varepsilon, \mu, \vec{\omega})=E(\mathrm{i}, \mathrm{j}, \varepsilon, \mu, \vec{\omega}) \mathrm{r}_{\mathrm{r}}(\mathrm{i}, \mathrm{j}, \varepsilon, \mu, \vec{\omega}),
$$

де $\mathrm{E}(\mathrm{i}, \mathrm{j}, \varepsilon, \mu, \vec{\omega})$ спектральне поле освітленості, що створюється елементом зображення $(\mathrm{i}, \mathrm{j})$ в момент часу $\mathrm{t}$, який характеризується електрофізичними параметрами $\varepsilon, \mu$ (діелектрична та магнітна проникності);

$$
\mathrm{r}_{я}(\mathrm{i}, \mathrm{j}, \varepsilon, \mu, \vec{\omega}) \quad \text { спектральний коефіцієнт }
$$

яскравості;

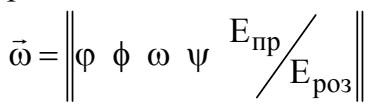
вектор умов

спостереження і освітлення, який визначається наступними параметрами:

$\phi$ та $\varphi$ кути спостереження елементу ПВ;

$\omega$ та $\psi$ кути освітлення елементу ПВ;

$\mathrm{E}_{\text {пр }}$ та $\mathrm{E}_{\text {роз }}$ випадкові поля освітленості, що створюються прямою і розсіяною радіацією.

Відповідно до обраного інформативного параметру ідеалізована модель ТВ зображення ПВ (без урахування шумів) може бути представлена у вигляді матриці:

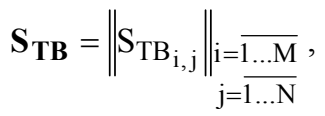

де $\mathrm{S}_{\mathrm{TB}}(\mathrm{i}, \mathrm{j})=\mathrm{f}\left(\mathrm{B}_{\text {я }}\right)$.

Відповідно ідеалізовану модель РМ зображення багатопроменевої системи представимо у матричному вигляді [2,3]:

$$
\mathbf{S}_{\mathbf{P M}}=\left\|\mathrm{S}_{\mathrm{PM}_{\mathrm{i}, \mathrm{j}}}\right\|_{\mathrm{j}=\overline{\mathrm{i}}=\overline{1 \ldots \mathrm{M}}},
$$

де $\mathrm{S}_{\mathrm{PM}}(\mathrm{i}, \mathrm{j})=\mathrm{f}\left(\mathrm{T}_{\mathrm{A}_{\mathrm{e \phi}}}\right)$.

Тоді формалізовану модель опису поточних зображень комбінованої КЕСН, що враховує фактори впливу, обумовлені як тримірною формою об'єктів ПВ, зміною просторового положення БПЛА так i похибками БІСН, в загальному вигляді представимо наступним чином. Для зображення, що сформоване РМ каналом:

$\mathrm{S}_{\mathrm{PM}}=\mathrm{f}\left(\mathrm{F}_{\mathrm{PM}}\left\{\mathrm{F}_{\mathrm{CP}}\left\{\begin{array}{l}\mathrm{F}_{0}\left(\mathrm{~T}_{0}+\delta \mathrm{T} ; \chi_{\mathrm{j}}\left(\dot{\varepsilon}_{\mathrm{j}}, \dot{\mu}_{\mathrm{j}}, \lambda, \varphi, \phi, \mathrm{D}, \mathrm{t}\right)+\right. \\ \left.+\delta \chi_{\mathrm{j}} ; \mathrm{T}_{\mathrm{aTM}}+\delta \mathrm{T}_{\mathrm{aTM}}\right) \\ \mathrm{F}_{\phi}\left(\mathrm{T}_{0}+\delta \mathrm{T} ; \chi_{\mathrm{i}}\left(\dot{\varepsilon}_{\mathrm{i}}, \dot{\mu}_{\mathrm{i}}, \lambda, \varphi, \phi, \mathrm{D}, \mathrm{t}\right)+\right. \\ \left.+\delta \chi_{\mathrm{i}} ; \mathrm{T}_{\mathrm{aTM}}+\delta \mathrm{T}_{\mathrm{aTM}}\right)\end{array}\right\}\right),(6)\right.$ де $\mathrm{F}_{\mathrm{PM}}, \mathrm{F}_{\mathrm{CP}}, \mathrm{F}_{0}, \mathrm{~F}_{\mathrm{\phi}}$ - оператори, що описують радіометр, середовище розповсюдження сигналів, об'єкт прив'язки ПВ та фон;

$\mathrm{T}_{0}+\delta \mathrm{T}-$ термодинамічна температура та іiі варіації;

$\chi_{\mathrm{j}}+\delta \chi_{\mathrm{j}}, \chi_{\mathrm{i}}+\delta \chi_{\mathrm{i}}-$ випромінювальна здатність об’єкту та фону;

$\lambda$ - довжина хвилі;

D - форма об'єкту візування;

$\mathrm{T}_{\mathrm{aTm}}+\delta \mathrm{T}_{\mathrm{aTм}}-$ радіотеплова температура та ii варіації.

Для зображення, що сформоване ТВ каналом:

$$
\mathrm{S}_{\mathrm{TB}}=\mathrm{f}\left(\mathrm{F}_{\mathrm{TB}}\left\{\mathrm{F}_{\mathrm{CP}}\left\{\begin{array}{l}
\mathrm{F}_{0}\left(\mathrm{~B}_{Я_{0}}\left(\varepsilon_{\mathrm{j}}, \mu_{\mathrm{j}}, \vec{\omega}, \mathrm{t}\right)\right) \\
\mathrm{F}_{\phi}\left(\mathrm{B}_{Я_{\phi}}\left(\varepsilon_{\mathrm{j}}, \mu_{\mathrm{j}}, \vec{\omega}, \mathrm{t}\right)\right)
\end{array}\right\}\right\},\right.
$$

де $\mathrm{B}_{Я_{0}}, \mathrm{~B}_{Я_{\phi}}-$ яскравість об'єкту та фону.

Враховуючи, що у виразі (7) $\vec{\omega}=\mathrm{f}(\varphi, \phi)$, зазначимо, що співвідношення (6) та (7) для опису ПЗ обох каналів, безвідносно до інформативного параметру, в загальному випадку не відрізняються. Ця обставина дозволяє здійснити уточнення опису моделей ПЗ в залежності від просторового положення БПЛА.

Не знижуючи спільності міркувань здійснимо уточнення моделі ПЗ, що формується каналами комбінованої КЕСН на прикладі РМ каналу 3 інформативним параметром - радіояскравісною температурою, 3 подальшим узагальненням на оптико-електронний канал.

Побудову моделі ПЗ будемо здійснювати 3 урахуванням наступних умов:

1) БпЛА здійснює політ рівномірно та прямолінійно зі швидкістю $\mathrm{V}$ під кутом $\varphi$ до вертикалі;

2) ДСА апроксимується гаусівською поверхнею;

3) Формування кадру ПЗ здійснюється багатопроменевою (матричною) системою;

4) П3 формується відповідно до $(6,7)$ в кожному каналі під впливом адитивного шуму;

5) вплив зміни просторового положення БПЛА на ПЗ здійснюється за кутом рискання $\psi^{\prime}=\psi \pm \Delta \psi$;

6) кути тангажа та крену не змінні.

Припустимо, що БпЛА рухається в площині $\mathrm{xz}$ системи координат $\mathrm{x}, \mathrm{y}, \mathrm{z}$, що пов'язана 3 ПВ (рис. 1 - а). Положення кожної парціальної ДСА характеризується кутами $\beta$ и $\alpha$. Кути розкриву ДСА на рівні половинної потужності дорівнюється $\theta_{\mathrm{x}}$ в площині за кутом місця та $\theta_{\mathrm{y}}-$ в азимутальній площині. Для гаусівської апроксимації ДСА іï перетин площиною ху представляє еліпс.

Відповідно до (5) ПЗ формується у вигляді матриці з М рядків та $\mathrm{N}$ стовбців. Нахил площини, в якій знаходяться ДСА за осями, заданий 
кутом $\beta_{\mathrm{i}, \mathrm{j}} \in \overline{1, \mathrm{M}}$ відносно вектора швидкості V, a положення вісі кожної ДСА в рядку характеризується кутом $\alpha_{\mathrm{ij}}$.

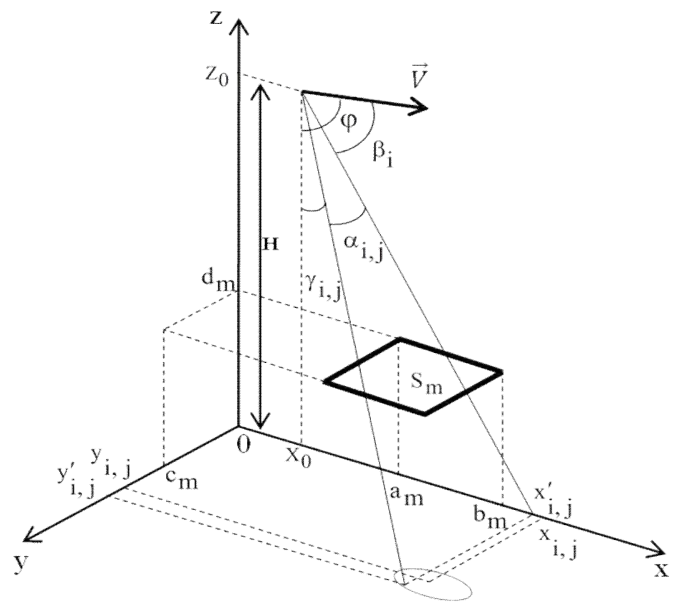

a)

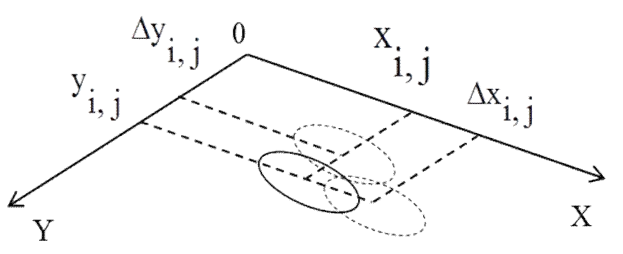

б)

Рисунок 1 - Геометричні умови формування ПЗ КЕСН БПЛА: а) положення ДСА РМ датчика в площині xуz; б) парціальна ДСА при випадковій зміні просторового положення БпЛА

Спотворення кадру ПЗ можуть бути знайдені 3 рівняння руху центрів та розмірів головних півосей еліпсів половинної потужності для кожного променя ДСА.

Опускаючи проміжні викладки, отримаємо вирази які описують зсув парціальної ДСА радіометра по координатам ху при зміні просторового положення БПЛА:

$$
\delta_{\mathrm{x}_{\mathrm{ij}}}=\frac{\Delta \mathrm{x}_{\mathrm{ij}}}{\sqrt{2 \ln 2}} ; \delta_{\mathrm{y}_{\mathrm{ij}}}=\frac{\Delta \mathrm{y}_{\mathrm{ij}}}{\sqrt{2 \ln 2}},
$$

Врахуємо залежність радіояскравісної температури від часу на виході окремого каналу РМ. Для цього припустимо, що на ПЗ мають місце К зон з радіояскравісними температурами $\mathrm{T}_{\mathrm{m}}$, що розташовані на рівномірному фоні з температурою $\mathrm{T}_{\phi}$ Тоді з урахуванням перехідної характеристики радіометра виду $\mathrm{h}_{\mathrm{ij}}(\mathrm{t})=\frac{1}{\tau_{\mathrm{ij}}} \exp \left(-\mathrm{t} / \tau_{\mathrm{ij}}\right)$ з постійною часу $\tau_{\mathrm{ij}}$ та параметрів антенної системи $\mathrm{G}\left(\mathrm{x}, \mathrm{y}, \mathrm{x}_{\mathrm{ij}}(\mathrm{t}), \mathrm{y}_{\mathrm{ij}}(\mathrm{t})\right)$, антенна температура i-го каналу радіометра після інтегрування в межах $\mathrm{t}_{0}=\mathrm{t}-3 \tau$ до $\mathrm{t}$ буде описуватися виразом:

$$
\begin{aligned}
32^{\mathrm{A}_{\mathrm{ij}}} & \mathrm{t})= \\
& \left.\times\left[\Phi\left(\frac{\xi-\mathrm{x}_{\mathrm{ij}}(\mathrm{t})}{\delta \mathrm{x}}\right)-\mathrm{B}_{\mathrm{ij}}(\mathrm{t} \xi)\right] \mid \begin{array}{l}
\mathrm{K} \\
\mathrm{b}_{\mathrm{m}}
\end{array} \mathrm{T}_{\mathrm{m}=\mathrm{a}_{\mathrm{m}}}-\mathrm{T}_{\phi}\right) \Phi\left(\frac{\xi-\mathrm{y}_{\mathrm{ij}}\left(\mathrm{t}_{0}\right)}{\delta \mathrm{y}}\right) \mathrm{l}_{\mathrm{m}}^{\mathrm{d}_{\mathrm{m}}} \times \mathrm{c}_{\mathrm{m}} \times
\end{aligned}
$$

де

$$
\begin{aligned}
& \mathrm{B}_{\mathrm{ij}}(\mathrm{t}, \xi)=\exp \left(\frac{\mathrm{r}_{\mathrm{ij}}^{2}}{2}+\frac{\xi-\mathrm{x}_{\mathrm{ij}}\left(\mathrm{t}_{0}\right)}{\delta \mathrm{x}} \mathrm{r}_{\mathrm{ij}}-\frac{\mathrm{t}-\mathrm{t}_{0}}{\tau_{\mathrm{ij}}}\right) \times \\
& \times\left[\Phi\left(\frac{\xi-\mathrm{x}_{\mathrm{ij}}(\eta)}{\delta \mathrm{x}}+\mathrm{r}_{\mathrm{ij}}\right)\right]_{\eta=\mathrm{t}_{0}}^{\mathrm{t}} ; \\
& \mathrm{r}_{\mathrm{ij}}=\frac{\delta_{\mathrm{x}_{\mathrm{ij}}}}{\mathrm{V}_{\mathrm{x}_{\mathrm{ij}} \tau_{\mathrm{ij}}}}
\end{aligned}
$$

$\Phi(\xi)=\frac{1}{\sqrt{2 \pi}} \int_{-\infty}^{\xi} \mathrm{e}^{-\theta^{2} / 2} \mathrm{~d} \theta$

$i \in \overline{1, M} ; j \in \overline{1, N}$.

Вираз (9) представляє собою модель опису П3, що формується РМ каналом в залежності від просторового положення БпЛА та його орієнтації без урахування шумів каналу та дає можливість здійснювати розрахунки вихідних сигналів РМ каналу.

Урахування адитивних шумів каналу призводить до моделі ПЗ у вигляді:

$$
\begin{gathered}
\mathrm{S}_{\mathrm{PM}}(\mathrm{i}, \mathrm{j})=\mathrm{T}_{\phi}+\left.\sum_{\mathrm{m}=1}^{\mathrm{K}}\left(\mathrm{T}_{\mathrm{m}}-\mathrm{T}_{\phi}\right) \Phi\left(\frac{\xi-\mathrm{y}_{\mathrm{ij}}\left(\mathrm{t}_{0}\right)}{\delta \mathrm{y}}\right)\right|_{\mathrm{m}=\mathrm{c}_{\mathrm{m}}} ^{\mathrm{d}_{\mathrm{m}} \times} \\
\times\left[\Phi\left(\frac{\xi-\mathrm{x}_{\mathrm{ij}}(\mathrm{t})}{\delta \mathrm{x}}\right)-\mathrm{B}_{\mathrm{ij}}(\mathrm{t} \xi)\right] \mid \begin{array}{l}
\mathrm{b}_{\mathrm{m}}+\mathrm{n}(\mathrm{t}) \\
\xi=\mathrm{a}_{\mathrm{m}}
\end{array}
\end{gathered}
$$

Відповідно вираз, що описує модель ПЗ в ТВ каналі можна представити наступним чином:

$$
\begin{aligned}
\mathrm{S}_{\mathrm{TB}}(\mathrm{i}, \mathrm{j}) & =\mathrm{B}_{\phi}+\left.\sum_{\mathrm{m}=1}^{\mathrm{K}}\left(\mathrm{B}_{\mathrm{A}_{\mathrm{m}}}-\mathrm{B}_{\mathrm{s}_{\phi}}\right) \Phi\left(\frac{\xi-\mathrm{y}_{\mathrm{ij}}\left(\mathrm{t}_{0}\right)}{\delta \mathrm{y}}\right)\right|_{\xi=\mathrm{c}_{\mathrm{m}}} ^{\mathrm{d}_{\mathrm{m}}} \times \\
\times & \left.\times \Phi\left(\frac{\xi-\mathrm{x}_{\mathrm{ij}}(\mathrm{t})}{\delta \mathrm{x}}\right)-\mathrm{B}_{\mathrm{ij}}(\mathrm{t} \xi)\right] \mid \begin{array}{l}
\mathrm{b}_{\mathrm{m}}+\mathrm{n}(\mathrm{t}) . \\
\xi=\mathrm{a}_{\mathrm{m}}
\end{array}
\end{aligned}
$$

Вирази (10, 11) в узагальненому вигляді описують радіояскравісну температуру (яскравість) об'єкту візування без урахування роздільної здатності каналів формування зображень.

Врахуємо, що позірна радіояскравісна температура об'єкта визначається відповідно до виразу [2]:

$\mathrm{T}_{\mathrm{g}_{\mathrm{\Pi}}}=\chi \mathrm{K}(\mathrm{L}) \mathrm{T}_{0}+(1-\chi) \mathrm{K}(\mathrm{L}) \mathrm{T}_{\mathrm{g}_{\mathrm{H}}}+[1-\mathrm{K}(\mathrm{L})] \mathrm{T}_{\mathrm{aTM}}$ 
де $\mathrm{K}(\mathrm{L})=\exp (-0,23 \alpha \mathrm{L})-$ коефіцієнт послаблення випромінювання на шляху розповсюдження довжиною $\mathrm{L}=\mathrm{H} \sec \theta$;

$\alpha$ - погонний коефіцієнт послаблення [дБ/км];

$\mathrm{T}_{я_{\mathrm{H}}}$ - радіотеплова температура неба.

Вираз (12) описує позірну радіояскравісну температуру для умов, коли тілесний кут об'єкта перевищує ширину головного пелюстка ДСА.

Умови візування, а саме співвідношення висоти Н, з якої здійснюється візування об'єкта до його розмірів $\mathrm{S}_{0}$, обумовлюють необхідність уточнення виразу для удаваної радіояскравісної температури об'єкта. Це стосується умов застосування БпЛА, коли висота польоту БпЛА може бути менше 1 км, а розмір об'єкта прив'язки десятки метрів. В цьому випадку, відповідно до результатів робіт $[2,3]$, позірна радіояскравісна температура $\mathrm{T}_{Я_{\Pi}}$ повинна визначатися температурами окремих видимих поверхонь об'єкта візування 3 урахуванням впливу радіояскравісної температури стовпа атмосфери $\mathrm{T}_{\text {атм }}$ відбитої видимими ділянками поверхні візування:

$$
\mathrm{T}_{Я_{\text {п }}}=\frac{\mathrm{T}_{0} \sum \chi_{\mathrm{i}} \mathrm{S}_{\mathrm{i}(\chi)}+\mathrm{T}_{\text {атм }} \sum \mathrm{k}_{\mathrm{j}} \mathrm{S}_{\mathrm{i}(\mathrm{k})}}{\mathrm{S}_{0}},
$$

де $\mathrm{S}_{0}=\sum_{\mathrm{i}=1}^{\mathrm{n}} \mathrm{S}_{\mathrm{i}(\chi)}+\sum_{\mathrm{j}=1}^{\mathrm{m}} \mathrm{S}_{\mathrm{j}(\mathrm{k})}-$ площа видимих ділянок поверхні об'єкта, що характеризуються випромінювальною та відбивною здатністю;

$\mathrm{k}_{\mathrm{j}}$ - коефіцієнт відбиття.

Вплив на формування радіояскравісної температури відбивної поверхні об'єкта здійснює його орієнтація відносно небесної півсфери та кута візування РМ каналу КЕСН. Для урахування цих факторів припустимо, що плоский елементарний відбивач знаходиться в центрі просторової прямокутної системи координат $0, \mathrm{x}, \mathrm{y}, \mathrm{z}$ (рис.2).

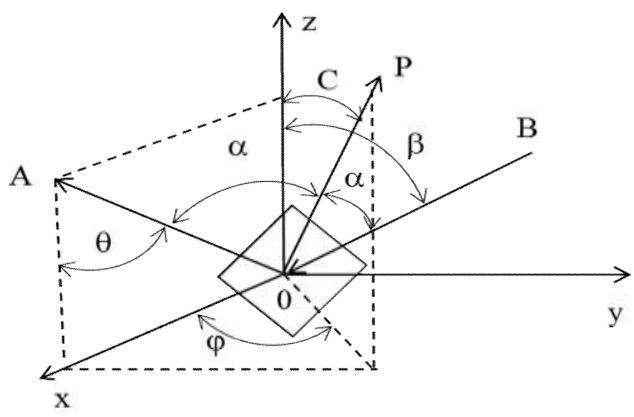

Рисунок 2 - Геометричні умови випромінювання стовпа атмосфери з напрямку ВО, відбитого елементарним відбивачем 3 нормаллю ОР в напрямку РМ датчика КЕСН

Радіотеплове випромінювання атмосфери, що падає під зенітним кутом $\beta 3$ напряму 0B, відбивається в напрямку 0 А під кутом $\alpha$. Зенітний кут випромінювання атмосфери $\beta$, кути падіння i відбиття $\alpha$, кут орієнтації елементарного відбивача С та $\varphi$, а також кут візування РМ датчика, відповідно до результатів робіт [2, 3], пов'язані наступними аналітичними виразами:

$$
\begin{aligned}
& \cos \alpha=\cos \varphi C \sin \theta+\cos \theta \cos C, \\
& \cos \beta=2 \cos \alpha \cos C-\cos \theta .
\end{aligned}
$$

Скористаємось результатами досліджень, що наведені в роботі [2] для визначення впливу тримірної форми об'єкта на визначення його радіояскравісної температури. Відомо, що характеристики випромінювання ПВ визначаються метеоумовами, при зміні яких з'являються варіації радіояскравісної температури. Тоді на підставі методу малих збільшень ці варіації можна представити таким чином:

$$
\delta \mathrm{T}_{Я}=\frac{\partial \mathrm{f}}{\partial \mathrm{T}_{0}} \mathrm{~T}_{0}+\frac{\partial \mathrm{f}}{\partial \chi} \chi+\frac{\partial \mathrm{f}}{\partial \mathrm{T}_{\text {атм }}} \mathrm{T}_{\text {aтм }}
$$

де $\partial \mathrm{T}_{0}, \partial \chi, \partial \mathrm{T}_{\text {атм }}-$ варіації, обумовлені зміною метеоумов, відповідно термодинамічної температури, випромінювальної здатності та температури неба.

3 урахуванням виразів $(13,14)$ вираз (15) запишемо:

$$
\mathrm{T}_{\boldsymbol{Я}_{\Pi}}=\frac{\sum_{\mathrm{i}=1}^{\mathrm{n}} \mathrm{S}_{\mathrm{i}}\left(\left(\chi_{\mathrm{i}}+\delta \chi_{\mathrm{i}}\right)\left(\mathrm{T}_{0}+\delta \mathrm{T}_{0}\right)+\mathrm{k}_{\mathrm{i}}\left(\mathrm{T}_{\boldsymbol{Я}_{\text {атм }}}+\delta \mathrm{T}_{\left.{Я_{\text {атм }}}\right)}\right)\right.}{\mathrm{S}_{0}},
$$

Для визначення $\mathrm{T}_{Я_{\Pi}}$ об’єкта дослідження складної тримірної форми, його розбивають на елементарні частини у вигляді паралелепіпедів і визначають їх вклад в формування радіояскравісної температури окремо, а потім в цілому.

Відповідно до рис. 3 у горизонтально розташованого паралелепіпеда зі сторонами a, b, c, при орієнтації щодо системи координат $\mathrm{x}, \mathrm{y}, \mathrm{z}$ відносно спостерігача одночасно буде видно не більше трьох площин паралелепіпеда $-\mathrm{S}_{2}, \mathrm{~S}_{5}, \mathrm{~S}_{6}$.

Видима поверхня його буде мати площу: $S_{B}=\sum_{i=1}^{n=3} S_{i} \cos \theta_{i}$, де $S_{1}=S_{4}=a b, S_{2}=S_{5}=a c, S_{3}=S_{6}=b c$.

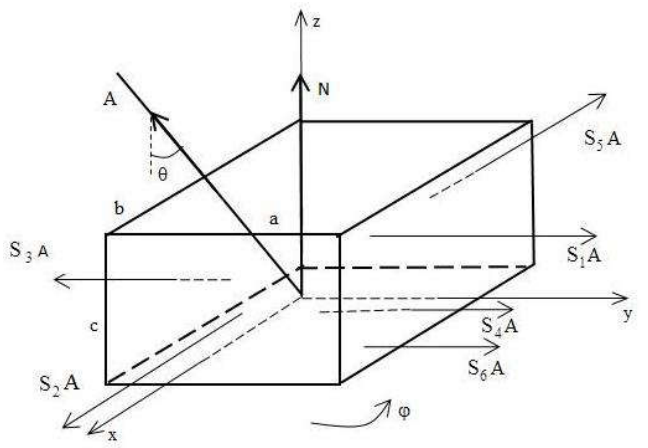


Рисунок 3 - Орієнтація паралелепіпеда відносно спостерігача

Враховуючи вище сказане радіояскравісна температура паралелепіпеда, що визначається співвідношеннями його видимих площин, буде описуватися виразом:

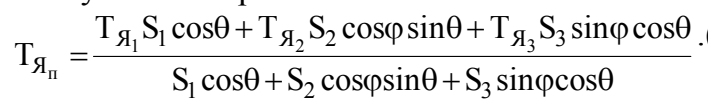

Аналогічно буде визначатися радіояскравісна температура об'єкта, який можна представити як сукупність двох і більше паралелепіпедів, сторона кожного з яких попадає в ДСА РМ датчика БпЛА при коефіцієнті заповнення близькому до одиниці.

У відповідності до рис. 4 значення кутів візування визначені через висоту БпЛА $\mathrm{H}_{1}$, висоту (ширину) площини $\mathrm{H}_{2}$ приблизно можна визначити у відповідності до співвідношень: $\theta_{2}=\operatorname{argctg}\left(\frac{\mathrm{H}_{1}-\mathrm{H}_{2}}{\mathrm{R}^{\prime}+\mathrm{H}_{2} / 2}\right), \theta_{3}=\operatorname{argctg}\left(\frac{\mathrm{H}_{1}-1,5 \mathrm{H}_{2}}{\mathrm{R}^{\prime}+\mathrm{H}_{2}}\right)$,
$\theta_{4}=\operatorname{argctg}\left(\frac{\mathrm{H}_{1}-2 \mathrm{H}_{2}}{\mathrm{R}^{\prime}+1,5 \mathrm{H}_{2}}\right)$, де $\mathrm{R}^{\prime} \approx\left(\mathrm{H}_{1}-\frac{\mathrm{H}_{2}}{2}\right) \operatorname{tg}\left(\theta_{1}\right)$.

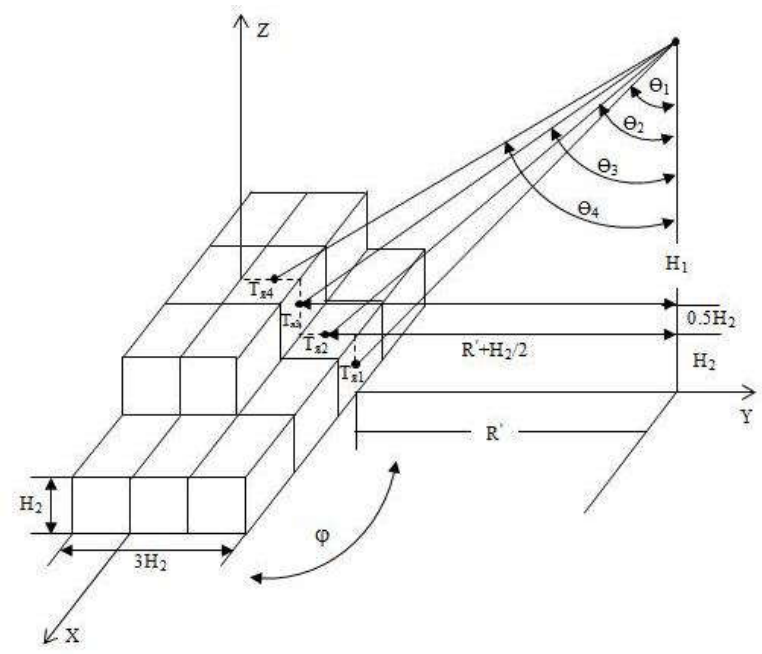

Рисунок 4 - Геометрія візування об'єкта дослідження РМ датчиком БпЛА

Співвідношення представлені виразами (16, 17) дозволяють розрахувати радіояскравісну температуру об'єкта візування на малих висотах в умовах коли елементарні площадки об'єкту візування за своїм розміром перевищують розміри парціальної діаграми спрямованості радіометра.

В якості прикладу визначимо розподіл радіояскравісної температури в межах об'єкту візування при умові, що площа об'єкту візування більша площі парціальної діаграми спрямованості радіометра.

На рис. 5 представлений графік зміни радіояскравісної температури окремих ділянок тримірного об'єкту візування в залежності від кутів візування отриманий шляхом математичного моделювання. Умови моделювання:

1) висота візування - 500м;
2) радіояскравісна температура неба - 50К;

3) термодинамічна температура - 300К;

4) кути розкриву ДСА радіометра $-30^{\circ} \times 40^{0}$;

5) ширина парціальної ДСА - $1^{0}$;

6) робоча частота - 3,2 мм;

7) кути візування - $90^{\circ}, 60^{\circ}, 45^{\circ}$;

8) розміри пікселя на зображенні - 8x8м.

Параметри об'єкта візування:

1) тримірний об'єкт складної форми (відповідно до pис. 1);

2) розміри об'єкта візування (в надір) - 10х30 м;

3) площа окремих ділянок об'єкта змінюється відповідно до кутів візування;

4) випромінювальні здатності елементів об'єкта: - горизонтальні площадки (бетон) - 0,76; - вертикальні площадки(цегла) - 0,82.

Параметри фону:

1) матеріал фону - асфальт;

2) випромінювальна здатність фону - 0,85.
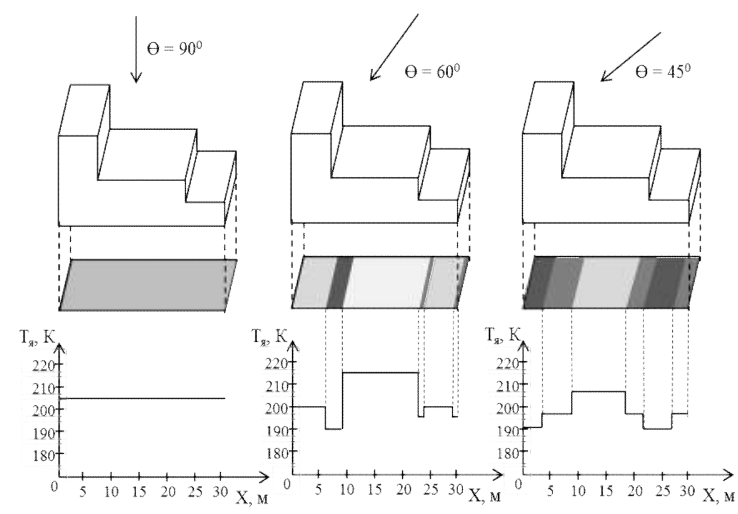

Рисунок 5 - Розподіл радіояскравісної температури по площі об'єкту візування: а) при куті візування $90^{\circ}$; б) при куті візування $60^{\circ}$; в) при куті візування $45^{0}$

Таким чином, результати математичного моделювання підтверджують необхідність урахування тримірної форми об'єктів візування при формуванні зображень в РМ каналі КЕСН, оскільки зміна кутів візування призводить до перепадів радіояскравісної температури i, як наслідок, до появи нових границь розділу в межах одного об'єкту візування.

Відповідно до цього, перепад радіояскравісної температури буде призводити до зміни структури поточного зображення в залежності від кута візування, що обумовлює необхідність пошуку нових підходів до формування поточних зображень за допомогою додаткових інваріантних ознак.

\section{Висновки й перспективи подальших досліджень}

Таким чином, здійснено уточнення моделі П3, що формується окремими каналами за інформативними ознаками в залежності від просторового положення БпЛА та його зміни.

Враховано вплив тримірної форми об'єктів 34 ISSN2311-7249(Print)/ISSN2410-7336(Onfine) Сучасні інббормаиійні технологіїу сббері безпеки та оборони № 2 (32)/2018 
ПВ на ефективну антенну температуру РМ каналу, що дозволило здійснити уточнення моделі опису РМ та ТВ ПЗ в залежності від інформативних ознак.

Визначено, що потребують розробки методи та алгоритми порівняння Е3 та ПЗ, які б вирішували завдання формування унімодальної ВФ в умовах спотворень ПЗ, обумовлених впливом тримірної форми об'єктів візування, просторового положення БПЛА та зміни його орієнтації.

\section{Лimepamypa}

1. Савенков А. И. Разработка высокоточных всепогодных систем наведения малоразмерных средств поражения объектов ВВТ. Оборонная техника. 1990. № 9. С. 18-19. 2. Антюфеев В. И. Матричные радиометрические корреляционно-экстремальные системы навигации летательных аппаратов монография / В. И. Антюфеев, В. Н. Быков, А. М. Гричанюк [и др.]. - Харьков : ХНУ им. В. Н. Каразина, 2014. - 372 с. 3. Антюфеев В. И. Радиометрические корреляционно-экстремальные системы навигации летательных аппаратов / В. И. Антюфеев, В. Н. Быков, А. М. Гричанюк, В. А. Краюшкин. - Харьков : ХНУ им. В. Н. Каразина, 2008. - 356 с. 4. Пат. 122637, Україна, Спосіб формування вирішальної функції кореляційно-екстремальних систем навігації за критерієм максимуму узагальненого коефіцієнта взаємної кореляції / О. М. Сотніков, В. А. Таршин, Р. Г. Сидоренко, О. Б. Танцюра, Г. В. Мегельбей, В. І. Грідін, А. І. Рєзніченко, Н. С. Єрьоміна № 122637, опубл . 25.01.2018. 5. Таршин В. А. Принципы формирования сложных эталонных изображений для высокоточных корреляционно-экстремальных систем навигации. / В. А. Таршин, А. М. Сотников,
Встановлено, що потребують подальшого розвитку методи формування Е3 для застосування в комбінованих $\mathrm{KECH,} \mathrm{які} \mathrm{повинні} \mathrm{враховувати} \mathrm{як}$ особливості побудови комбінованої КЕСН, так i порядок формування ВФ.

Результати розробки моделі опису ПЗ ПВ комбінованої КЕСН визначають напрямки подальших досліджень в області формування ЕЗ та ВФ КЕСН основою яких $\epsilon$ представлена модель ПЗ комбінованих КЕСН.

Р. Г. Сидоренко // Системи обробки інформації. 2014. — № 6. - С. 86-89. 6. Сидоренко Р. Г. Метод підвищення завадостійкості радіометричних систем землеогляду на основі придушення зосереджених завад у радіометрі при підвищенні чутливості за рахунок накопичення та декореляції шумів : автореф. дис. ... канд. техн. наук : 05.12.17 / Р. Г. Сидоренко. — Х., 2007. - 21 с. 7. Баклицкий В. К. Корреляционноэкстремальные методы навигации и наведения / В. К. Баклицкий. - Тверь : Книжный клуб, 2009. - 360 с. 8. Щербинин B. В. Построение инвариантных корреляционно-экстремальных систем навигации и наведения летательных аппаратов / В.В.Щербинин. М. : МГТУ им. Н. Э. Баумана, 2011. - 230 с. 9. Потапов A. А. Новейшие методы обработки изображений : монография / А. А. Потапов, Ю. В. Гуляев, С. А. Никитович [и др.]. - М. : ФИЗМАТЛИТ, 2008. - 400 с. 10. Гонсалес Р. Цифровая обработка изображений в среде MATLAB / Р. Гонсалес, Р. Вудс, С. Эддинс. - М. : Техносфера, 2006. - 616 с.

\title{
МОДЕЛИ ТЕКУЩИХ ИЗОБРАЖЕНИЙ, ЧТО ФОРМИРУЮТСЯ КНАЛАМИ КОМБИНИРОВАННОЙ КОРРЕЛЯЦИОННО-ЭКСТРЕМАЛЬНОЙ СИСТЕМЫ НАВИГАЦИИ БЕСПИЛОТНОГО ЛЕТАТЕЛЬНОГО АППАРАТА
}

\author{
Воробвёв Олег Михайлович (доктор техн наук, профессор) ${ }^{1}$ \\ Сотников Александр Михайлович (докторр техн наук, проессор) ${ }^{2}$ \\ Танцюра Александр Борисович ${ }^{2}$
}

\begin{abstract}
${ }^{1}$ Национальный университет обороны Украины имени Ивана Черняховского, Киев, Украина ${ }^{2}$ Харьковский национальный университет Воздушных Сил имени Ивана Кожедуба, Харьков, Украина
\end{abstract}

Осуществлено уточнение модели текущих изображений, что формируются отдельными каналами комбинированной корреляционно-экстремальной системы навигации в зависимости от пространственного положения беспилотного летательного аппарата и его изменений. В модели учтено влияние трехмерной формы сложных объектов поверхности визирования на эффективную антенную температуру радиометрического канала и на яркость телевизионного канала. Это позволило совершить уточнение модели описания радиометрического и телевизионного текущего изображения поверхности визирования в зависимости от информативных признаков. Определено, что при малых высотах визирования изменение пространственного положения беспилотного летательного аппарата приводит к существенным перепадам радиояркостной температуры в пределах одного объекта визирования, что обуславливает размытие и появление новых грании раздела на текущем изображении поверхности визирования. Несоответствие текущего изображения эталонному, которое возникает вследствие появления новых грании раздела при визировании сложных трехмерных объектов с малых высот и при изменении пространственного положения и ориентации беспилотного летательного аппарата, приводит к формированию многоэкстремальной решающей функции и уменьшению точности местоопределения корреляционно-экстремальной системы навигации.

Ключевые слова: радиояркостная температура; трехмерный объект визирования; текущее изображение; пространственное положение; комбинированная корреляичонно-экстремальная система Modern Information Technologies in the Sphere of Security and Defence № 2(32)/2018 ISSN2311-7249(Print)/ISSSN2410-7336(Onfine) 35 
навигации; беспилотный летательный аппарат.

\title{
MODELS OF CURRENT IMAGES THAT ARE FORMED BY THE COMBINED CORRELATION- EXTREMAL NAVIGATION SYSTEM OF A NON-FLAMMABLE AIRCRAFT
}

\author{
Oleg M. Vorobiov (Doctor of Technical Sciences, professor) ${ }^{1}$ \\ Alexander M. Sotnicov (Doctor of Technical Sciences, professor) ${ }^{2}$ \\ Alexander B. Tansiura ${ }^{2}$
}

\section{National Defense University of Ukraine named after Ivan Chernyhovski, Kyiv, Ukraine ${ }^{1}$ Kharkiv National University named after Ivan Kozhedub Air Force, Kharkiv, Ukraine ${ }^{2}$}

A refinement of the current image model has been accomplished, which are formed by separate channels of the combined correlation-extreme navigation system depending on the spatial position of the unmanned aerial vehicle and its changes. The model takes into account the influence of the three-dimensional shape of complex objects of the sighting surface on the effective antenna temperature of the radiometric channel, which made it possible to refine the moles of the description of the radiometric and television current image of the sighting surface, depending on the informative features. It is determined that at small viewing altitudes the change in the spatial position of the unmanned aerial vehicle leads to significant differences in the radio brightness temperature within a single sighting object, which causes the blurring and appearance of new interfaces on the current image of the viewing surface. It is established that the discrepancy between the current image and the reference image, which arises from the appearance of new interfaces at the sight of complex three-dimensional objects from low altitudes and with a change in the spatial position and orientation of the unmanned aerial vehicle, leads to the formation of a multi-extremal decision function and a decrease in the accuracy of the location of the correlation-extreme navigation system.

Key words: radio brightness temperature; $3 D$ object of sight; current image; spatial position; combined correlation-extreme navigation system; unmanned aerial vehicle.

\section{References}

1. Savenkov A.I. (1990), Development of high-precision all-weather guidance systems for small-sized weapons of destruction of weapons and military equipment. [Razrabotka vysokotochnykh vsepogodnykh sistem navedeniya malorazmernykh sredstv porazheniya ob"yektov VVT], Defense technology. № 9. pp. 18-19. 2. Antyufeev V.I. (2014) Matrix radiometric correlation-extreme navigation systems for aircraft: monograph [Matrichnyye radiometricheskiye korrelyatsionno-ekstremal'nyye sistemy navigatsii letatel'nykh apparatov : monografiya], Kharkov: KhNU V.N. Karazin, 372 p. 3. Antyufeev V.I. (2008) Radiometric correlation-extreme navigation systems of aircrafts [Radiometricheskiye korrelyatsionnoekstremal'nyye sistemy navigatsii letatel'nykh apparatov], Kharkov: KhNU V.N. Karazin, 356 p. 4. Sotnikov A.M. (2018) A method of forming the decisive function of correlation-extreme navigation systems according to the criterion of the maximum of the generalized coefficient of mutual correlation [Sposib formuvannya vyrishal noyi funktsiyi korelyatsiyno-ekstremal nykh system navihatsiyi za kryteriyem maksymumu uzahal nenoho koefitsiyenta vzayemnoyi korelyatsiyi] Pat. 122637, Ukraine. 5. Tarshin V.A. (2014) Principles of formation of complex reference images for high-precision correlation-extreme navigation systems [Pryntsypy formyrovanyya slozhnykh étalonnykh yzobrazhenyy dlya vysokotochnykh korrelyatsyonno- ékstremal nykh system navyhatsyy], Systems of information processing. № 6, pp. 86-89. 6. Sidorenko R.G. (2007) Method of increasing the noise immunity of radiometric systems of land surveying on the basis of suppression of concentrated disturbances in a radiometer with increasing sensitivity due to accumulation and decoloration of noise [Metod pidvyshchennya zavadostiykosti radiometrychnykh system zemleohlyadu na osnovi prydushennya zoseredzhenykh zavad $u$ radiometri pry pidvyshchenni chutlyvosti za rakhunok nakopychennya ta dekorelyatsiyi shumiv], author's abstract. dis. candidate tech sciences, Kharkiv, 21 p. 7. Baklitsky V.K. (2009) Correlationextremal methods of navigation and guidance [Korrelyatsionno-ekstremal'nyye metody navigatsii i navedeniya], Tver: Book Club, 360 p. 8. Shcherbinin V.V. (2011) Construction of invariant correlation-extremal systems of navigation and guidance of aircraft [Postroyeniye invariantnykh korrelyatsionno-ekstremal'nykh sistem navigatsii $i$ navedeniya letatel'nykh apparatov], Moscov.: MGTU them. N. E. Baumana, 230 p. 9. Potapov A.A. (2008) Newest Methods for Image Processing [Noveyshiye metody obrabotki izobrazheniy], Moscov: FIZMATLIT, 400 p. 10. Gonzalez R. (2006) Digital Image Processing in the MATLAB [Tsifrovaya obrabotka izobrazheniy $v$ srede $M A T L A B]$, Moscow: Technosphere, 616 p. 